\title{
Study of Morphometry of Clavicle in East Indian Population
}

\section{ABSTRACT}

Introduction: The clavicle is a subcutaneous bone most frequently fractured at the junction of medial $2 / 3^{\text {rd }}$ and lateral $1 / 3^{\text {rd }}$ of its shaft. The knowledge about the morphometry of clavicle is important for surgeons as well as orthopaedic surgeons.

Aim: The aim of this study is to measure the variation of length, medial and lateral angle in east Indian population.

Materials and Methods: In this observational cross-sectional study, 54 dry adult clavicle (25 males, 29 females) were collected from the first year medical students of various colleges of West Bengal (east India). The length, medial and lateral angles were measured. The data obtained was tabulated in Microsoft Excel sheet and then transferred to IBM Statistical Package for the Social Sciences (SPSS) version 23. The data was analysed using Independent Sample t-test assuming unequal variances, taking $\mathrm{p}<0.05$ as statistically significant.
Results: The average mean length of left sided clavicle was slightly more in both male and female than the right side. But this difference was statistically nonsignificant as $p$-value was 0.768 (male) and 0.74 (female). In male, the average lateral angle of left side was more than the right side but not so in case of female where the right side was more than the left side. This difference was statistically significant in case of both male ( $p$-value $=0.0008)$, and female ( $p$-value $=0.0001)$. In case of medial angle, it was more in left side in both males and females. The difference was also significant in both males ( $p$-value 0.0001) and females ( $p$-value $=0.00001$ ).

Conclusion: The present study revealed that the average length of clavicle in case of males are more in right and left side than females. The lateral angle is more for females on right side and more for males on the left side. The medial angle is more for females on both right and left side as compared to males.

\section{INTRODUCTION}

The clavicle, one of the bones of shoulder girdle is a subcutaneous bone and lies horizontally at the root of the neck. It keeps the upper limb away, so that it can swing clearly from the side of the trunk. It transmits the weight of the upper limb through the coraco-clavicular ligament and medial $2 / 3^{\text {rd }}$ of the bone to the axial skeleton [1]. It has a shaft and two ends-medial or sternal end and lateral or acromial end. The length of female clavicle is shorter than the male [1]. The clavicle gradually changes its shape from tubular (medially) to flat (laterally). It is probably the most common bone which is fractured in adults and children by an indirect violence due to a fall on an outstretched hand. It constitutes $44-66 \%$ of all shoulder fractures [2]. Most of the fractures occur at the junction of medial $2 / 3^{\text {rd }}$ and lateral $1 / 3^{\text {rd }}$ of the shaft. Usually, the fractures are treated conservatively, but there is increased chance of non-union and morbidity associated with the displaced fracture. So now-a-days open reduction and internal plate fixation becomes much more popular, because it has high union rate and less complications [3]. These surgical approaches demand a thorough knowledge about the anatomy and the variation of clavicle. Though many studies were conducted throughout the world to know the variation of curvature of clavicle [1-13]. In eastern India also studies were conducted $[14,15]$ to observe the variations. The present study was done to find out the differences between the length and medial and lateral angles of clavicle in both sexes.

\section{MATERIALS AND METHODS}

An observational cross-sectional study design was adopted to compare the quantitative data after the due permission from Departmental Head. In this study, 54 dry clavicles were taken, out of which 25 were male and rest 29 were female (depending upon the bony features sex determination was done). All the bones for this study were collected from different medical colleges instead of single college of West Bengal so that they represent east Indian population. The work was started from April 2019 and completed it on June 2020. As this study was done on dry bones, so, only the verbal permission from the Head of the Department of Anatomy of respective colleges were taken. To measure the length i.e., the straight maximum distance between the two ends Vernier Caliper (taken from Anatomy Department of one college) was used. Parson's method [5] was followed to measure the angles. The clavicle was placed on a white board with right and left ends in the same horizontal plane. An outline of the clavicle was drawn on the paper. The midpoint of the sternal and acromial ends was marked as points 'a' and ' $b$ '. They were joined with a straight line. The central axis was a curved line and it was equidistant from the anterior and posterior border throughout the length of the clavicle. This curved line has two convexities. Two deepest points on this line where the bone has maximum convexities were marked as 'c' and 'd'. Now ' $a$ ' and 'c', 'c' and ' $d$ ', ' $d$ ' and 'b' are joined with a straight line [Table/Fig-1a,b] [6].

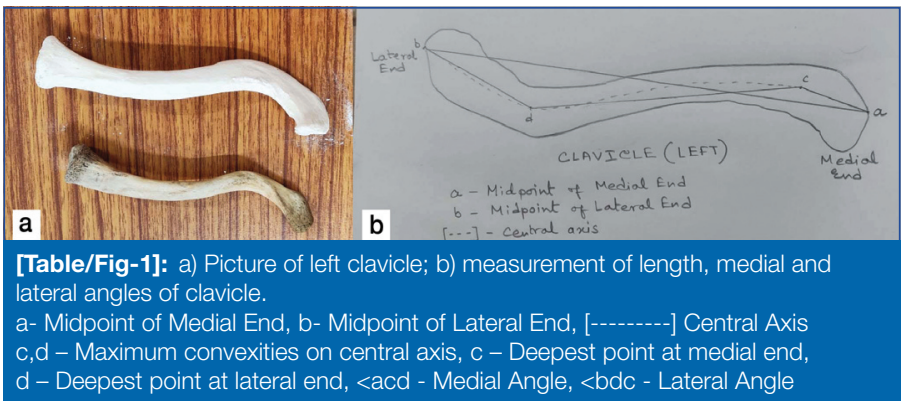

Thus, two angles were formed, one at medial side and another on lateral side of the bone. Now the angles were measured with the help of a protractor. The same procedure was applied for all the bones. 
The measurements were recorded twice by single person (who has done this type of work before) to eliminate the inter-examiner variations, and then the average were calculated to minimise error.

\section{STATISTICAL ANALYSIS}

The data obtained was tabulated in Microsoft Excel sheet and then transferred to IBM SPSS version 23. The data was analysed using Independent Samples t-test assuming unequal variances, taking $\mathrm{p}<0.05$ as statistically significant.

\section{RESULTS}

A total of 54 dry clavicles, out of which 25 were male and rest 29 were female. The data on length, lateral angles, and medial angles of clavicle of left and right sides in males and females have been compared [Table/Fig-2-4].

\begin{tabular}{|l|c|c|c|c|c|}
\hline Data & \multicolumn{2}{|c|}{ Length (cm) } & \multicolumn{2}{c|}{ Standard deviation } & \multirow{2}{*}{ p-value } \\
\hline Sample size & Right & Left & Right & Left & 0.768 \\
\hline Male (25) & 13.88 & 14.04 & 1.364 & 0.946 & 0.740 \\
\hline Female (29) & 11.9 & 12.02 & 0.937 & 0.970 & 0.740 \\
\hline p-value & 0.002 & $<0.001$ & & \\
[Table/Fig-2]: Comparison of length of clavicle between males and females. \\
(Independent sample t-test assuming unequal variances was done); $p<0.05$ statistically significant
\end{tabular}

\begin{tabular}{|l|c|c|c|c|c|}
\hline Data & \multicolumn{2}{|c|}{$\begin{array}{c}\text { Mean lateral angles } \\
\text { (in degrees) }\end{array}$} & \multicolumn{2}{c|}{ Standard deviation } & \multirow{2}{*}{ p-value } \\
\hline Sample size & Right side & Left side & Right side & Left side & 0.0008 \\
\hline Male (25) & 147.00 & 150.406 & 1.732 & 4.446 & 0.0001 \\
\hline Female (29) & 152.363 & 147.722 & 1.804 & 3.121 & 0.04 \\
\cline { 1 - 4 }$p$ p-value & 0.0001 & 0.0152 & & \\
[Table/Fig-3]: Comparison of right with left lateral angles of the clavicle in male \\
and female. \\
(Independent sample t-test assuming unequal variances was done); p<0.05 statistically significant
\end{tabular}

\begin{tabular}{|l|c|c|c|c|c|}
\hline Data & \multicolumn{2}{|c|}{$\begin{array}{c}\text { Mean medial angles (in } \\
\text { degrees) }\end{array}$} & \multicolumn{2}{c|}{ Standard deviation } & \multirow{2}{*}{ p-value } \\
\hline Sample size & Right side & Left side & Right side & Left side & 0.0001 \\
\hline Male (25) & 139.666 & 149.312 & 2.121 & 5.522 & 0.00001 \\
\hline Female (29) & 145.818 & 151.055 & 3.516 & 5.034 & 0.000 \\
\cline { 1 - 4 } $\mathrm{p}$-value & 0.0001 & 0.2341 & & \\
[Table/Fig-4]: Comparison of right with left medial angles of the clavicle in male \\
and female. \\
(Independent Sample t-test assuming unequal variances was done.); $\mathrm{p}<0.05$ statistically significant
\end{tabular}

The average length of clavicle of right side in male was $13.88 \mathrm{~cm}$ and of left side was $14.04 \mathrm{~cm}$, whereas the same in female was $11.9 \mathrm{~cm}$ (right side) and $12.02 \mathrm{~cm}$ (left side). Independent Samples t-test assuming unequal variances was done. Though the mean length was slightly more in left side compared to right, but the results were not statistically significant in both sexes as p-value was 0.768 (male) and 0.740 (female).

Comparing the length of both male and female samples, $\mathrm{p}$-value was 0.002 (right) and $<0.001$ (left). From this study, it can be concluded that the length of clavicle of left side was longer than right side in both male and female, though the difference was statistically insignificant. But the male clavicle was significantly longer than female in both sides. And the difference is statistically significant as $\mathrm{p}$-value is $<0.05$.

Here, Independent Sample t-test assuming unequal variances was done to compare the collected data. The mean lateral angle of clavicles in male was $147^{\circ}$ (right side) and $150.4^{\circ}$ (left side) and $\mathrm{p}$-value was 0.0008 but in female it was $152.363^{\circ}$ (right) and $147.7^{\circ}$ (left) respectively with the $p$-value $=0.0001$. Then, the study compared the lateral angle of both male and female, the $p$-value became 0.0001 (right side) and 0.0152 (left side) respectively, which is statistically significant (as $p<0.05)$.
Similar test (t-test) was also applied here. The mean medial angle of clavicle in male was $139.6^{\circ}$ (right side) and $149.3^{\circ}$ (left side) and p-value was 0.0001 but in female it was $145.8^{\circ}$ (right) and $151^{\circ}$ (left) respectively with the $p$-value $=0.00001$. Then, the study compared the medial angle of both male and female, the p-value became 0.0001 in right side (significant as p-value $<0.05$ ) and 0.2341 (left side) respectively (nonsignificant, $p$-value $>0.05$ )

\section{DISCUSSION}

Many studies have done to determine whether there are any variation in length and angles of clavicle of both sides in both sexes. These studies have been performed on different populations.

\section{Length}

In this study, average length of left clavicle is more than right in both sexes. But the same study done by Sudha R on South Indian population in the year 2014 the result was just opposite. Here, the researcher found that right clavicle was longer than left [4]. Other two studies done by Singh S and Gangrade KC in 1968 on Varanasi population [11], Nagarachi K et al., in 2014 on South Indian population also found the length of right clavicle was more than left [3]. But the following table showed that the maximum studies supported the findings. In 1916, a study was done by Parson FG on the population of England and it was observed that the left clavicle was longer than the right [5]. Similar results were found in various other studies conducted by Terry RJ on American Negroes and American White in 1932, Olivier G on French Population in 1951, Jit I and Singh S on population of Amritsar in 1956 and Haque MK et al., on Nepalese population in 2011 [7-10].

A study done by Singh $\mathrm{G}$ et al., in the year 2020 where researchers found that the right sided clavicle was longer than left side in Odisha population [14] [Table/Fig-5].

\begin{tabular}{|c|c|c|c|c|}
\hline Author & Population & $\begin{array}{l}\text { Sample } \\
\text { size }\end{array}$ & $\begin{array}{l}\text { Length of the } \\
\text { clavicle (cm) } \\
\text { (Right) }\end{array}$ & $\begin{array}{l}\text { Length of the } \\
\text { clavicle (cm) } \\
\text { (Left) }\end{array}$ \\
\hline $\begin{array}{l}\text { Parsons FG } \\
\text { (1916) [5] }\end{array}$ & England & 200 & 14.5 & 14.65 \\
\hline \multirow{2}{*}{$\begin{array}{l}\text { Terry RJ (1932) } \\
\text { [7] }\end{array}$} & $\begin{array}{l}\text { American- } \\
\text { Negroes }\end{array}$ & 100 & 14.71 & 14.88 \\
\hline & $\begin{array}{l}\text { American- } \\
\text { White }\end{array}$ & 50 & 15.29 & 15.41 \\
\hline $\begin{array}{l}\text { Olivier G (1951) } \\
\text { [8] }\end{array}$ & French & 170 & 14.60 & 14.8 \\
\hline $\begin{array}{l}\text { Jit I and Singh } \\
\text { S (1956) [9] }\end{array}$ & Amritsar & 348 & 13.79 & 13.86 \\
\hline $\begin{array}{l}\text { Haque MK et } \\
\text { al., (2011) [10] }\end{array}$ & Nepal & 257 & 14.32 & 14.55 \\
\hline $\begin{array}{l}\text { Singh S \& } \\
\text { Gangrade } \\
\text { KC(1968) [11] }\end{array}$ & Varanasi & 97 & 13.76 & 13.74 \\
\hline $\begin{array}{l}\text { Nagarchi K et } \\
\text { al., (2014) [3] }\end{array}$ & $\begin{array}{l}\text { South } \\
\text { Indian }\end{array}$ & 320 & $\begin{array}{c}14.21 \pm 1.170(\mathrm{~m}) \\
13.11 \pm 1.22(\mathrm{f})\end{array}$ & $\begin{array}{c}14.38 \pm 0.95(\mathrm{~m}) \\
13.11 \pm 0.90(\mathrm{f})\end{array}$ \\
\hline $\begin{array}{l}\text { Sudha R } \\
\text { (2014) [4] }\end{array}$ & $\begin{array}{l}\text { South } \\
\text { Indian }\end{array}$ & 113 & 13.763 & 13.748 \\
\hline $\begin{array}{l}\text { Singh G et al., } \\
(2020)[14]\end{array}$ & Odisha & 100 & $\begin{array}{c}143.28 \pm 4.67 \mathrm{~mm} \\
(\mathrm{~m}) \\
128.37 \pm 5.86 \\
\mathrm{~mm}(\mathrm{f})\end{array}$ & $\begin{array}{c}142.84 \pm 4.67 \mathrm{~mm} \\
127.52 \pm 5.96 \mathrm{~mm} \\
\text { (f) }\end{array}$ \\
\hline Present Study & East India & 54 & $\begin{array}{c}13.88(\mathrm{~m}) \\
11.9(\mathrm{f})\end{array}$ & $\begin{array}{l}14.04(\mathrm{~m}) \\
12.02(\mathrm{f})\end{array}$ \\
\hline
\end{tabular}

\section{Lateral Angle}

In the present study, the lateral angle of left side was significantly larger (as p-value 0.0008 i.e., <0.05) than right side in male but in female right sided lateral angle was more than the left side. And the difference was also statistically significant ( $p$-value <0.05). In 
previous studies done by others, it was observed that the lateral angle was more in left side in case of both male and female. But in the present study, it was not so in case of female where left lateral angle was less than right. In a previous study, done by Parson FG in 1916 among the population of England, it was reported that lateral angles were same in both sides in case of male but in female it was more in left side [5]. In all other studies done by Terry RJ [7] on American-Negros and American-Whites, Olivier G [8] on French population, Kaur $\mathrm{H}$ et al., on Chandigarh population [13], Haque MK et al., on Nepalese [10], Sudha R on South Indian population lateral angle of left side was more than the right in both male and female [4].

There were another two studies. One was done by Kaur $\mathrm{H}$ et al., in 2002 among North-West Indians (Chandigarh) [13] and another by Kaur K and Rathee SK among North Indian population in 2015 [12]. In both studies, lateral angle of left side was more in both sexes. In a separate study done by Kumari $S$ et al., among East Indian population in 2018 the lateral angle was more in left side [15] [Table/Fig-6].

\begin{tabular}{|c|c|c|c|c|c|c|}
\hline \multirow[b]{2}{*}{ Author } & \multirow[b]{2}{*}{ Population } & \multirow{2}{*}{$\begin{array}{l}\text { Sample } \\
\text { size }\end{array}$} & \multicolumn{2}{|c|}{$\begin{array}{c}\text { Male } \\
\text { (Lateral angle) }\end{array}$} & \multicolumn{2}{|c|}{$\begin{array}{c}\text { Female } \\
\text { (Lateral angle) }\end{array}$} \\
\hline & & & Right & Left & Right & Left \\
\hline $\begin{array}{l}\text { Parsons FG } \\
\text { (1916) [5] }\end{array}$ & England & 200 & 148 & 148 & 150 & 151 \\
\hline \multirow{2}{*}{$\begin{array}{l}\text { Terry RJ } \\
\text { (1932) [7] }\end{array}$} & $\begin{array}{l}\text { American- } \\
\text { Negroes }\end{array}$ & 100 & 138.42 & 143.54 & 144.06 & 145.82 \\
\hline & $\begin{array}{c}\text { American- } \\
\text { White }\end{array}$ & 50 & 139.25 & 142.66 & - & - \\
\hline $\begin{array}{l}\text { Olivier G } \\
(1951)[8]\end{array}$ & French & 170 & 141.8 & 143 & 145 & - \\
\hline $\begin{array}{l}\text { Kaur H et } \\
\text { al., (2002) } \\
\text { [13] }\end{array}$ & $\begin{array}{c}\text { North-West } \\
\text { Indian } \\
\text { (Chandigarh) }\end{array}$ & & 143.27 & 148.2 & 144.65 & 148.73- \\
\hline $\begin{array}{l}\text { Haque MK } \\
\text { et al., (2011) } \\
{[10]}\end{array}$ & Nepal & 257 & 139.76 & 141.73 & - & - \\
\hline $\begin{array}{l}\text { Sudha R } \\
\text { (2014) [4] }\end{array}$ & South India & 113 & 142.05 & 144 & - & - \\
\hline $\begin{array}{l}\text { Kaur K and } \\
\text { Rathee SK } \\
(2017)[12]\end{array}$ & North India & 160 & $\begin{array}{c}150.75 \\
\pm 8.56\end{array}$ & $\begin{array}{c}153.45 \\
\pm 8.94\end{array}$ & $\begin{array}{c}153.18 \\
\pm 8.33\end{array}$ & $\begin{array}{c}155.47 \\
\pm 7.79\end{array}$ \\
\hline $\begin{array}{l}\text { Kumari S et } \\
\text { al., (2018) } \\
{[15]}\end{array}$ & East India & 50 & $\begin{array}{l}148.87 \\
\pm 5.04\end{array}$ & $\begin{array}{l}151.62 \\
\pm 5.63\end{array}$ & - & - \\
\hline $\begin{array}{l}\text { Present } \\
\text { study }\end{array}$ & East India & 54 & 147.00 & 150.40 & 152.36 & 147.72 \\
\hline $\begin{array}{l}\text { [Table/Fig } \\
\text { studies [4,5 }\end{array}$ & $\begin{array}{l}\text { Oomparison } \\
10,12,13,15\end{array}$ & an la & angle & avicle $r$ & ted in & evious \\
\hline
\end{tabular}

\section{Medial Angle}

In the present study, the medial angle was more in left side in both male and female. Parson FG reported that the medial angle was equal on both sides in both sexes [5]. Terry RJ did another study on American-Negros where he reported that medial angle of right side was more than the left side in male but not so in female [7]. He also observed that in male the result was same in American-White. Various studies done by different research workers on different population yielded different results. Sudha $\mathrm{R}$ reported that medial angle was greater on the right side as compared to left side [4], but that did not match with the results of the study done by Olivier G, Haque MK et al., Kaur K and Rathee SK, and Kaur H et al., where the findings were just opposite $[8,10,12,13]$. They found that medial angle of left side was more than the right side.

Another study done by Kumari S et al., in the year 2018 in East Indian population reported that the medial angle was more in left side than the right side [15] [Table/Fig-7].

Several studies [1-13] have attempted on different population to determine both the angles and length of the clavicle. Similar studies

\begin{tabular}{|c|c|c|c|c|c|c|}
\hline \multirow[b]{2}{*}{ Author } & \multirow[b]{2}{*}{ Population } & \multirow{2}{*}{$\begin{array}{l}\text { Sample } \\
\text { size }\end{array}$} & \multicolumn{2}{|c|}{$\begin{array}{c}\text { Male } \\
\text { (Medial angle) }\end{array}$} & \multicolumn{2}{|c|}{$\begin{array}{c}\text { Female } \\
\text { (Medial angle) }\end{array}$} \\
\hline & & & Right & Left & Right & Left \\
\hline $\begin{array}{l}\text { Parsons FG } \\
\text { (1916) [5] }\end{array}$ & England & 200 & 153 & 153 & 155 & 155 \\
\hline \multirow{2}{*}{$\begin{array}{l}\text { Terry RJ } \\
\text { (1932) [7] }\end{array}$} & $\begin{array}{l}\text { American- } \\
\text { Negroes }\end{array}$ & 100 & 153.52 & 151.58 & 151.12 & 153.62 \\
\hline & $\begin{array}{l}\text { American- } \\
\text { White }\end{array}$ & 50 & 153.12 & 151.42 & - & - \\
\hline $\begin{array}{l}\text { Olivier G } \\
\text { (1951) [8] }\end{array}$ & French & 170 & 150.2 & 151.4 & 151 & - \\
\hline $\begin{array}{l}\text { Kaur H et } \\
\text { al., (2002) } \\
\text { [13] }\end{array}$ & Chandigarh & 165 & 150.76 & 150.94 & 152.61 & 152.82 \\
\hline $\begin{array}{l}\text { Haque MK } \\
\text { et al., (2011) } \\
\text { [10] }\end{array}$ & Nepal & 257 & 150.97 & 151.50 & - & - \\
\hline $\begin{array}{l}\text { Sudha R } \\
\text { (2014) [4] }\end{array}$ & South India & 113 & 147.5 & 146 & - & - \\
\hline $\begin{array}{l}\text { Kaur K and } \\
\text { Rathee SK } \\
(2017)[12]\end{array}$ & North India & 160 & $\begin{array}{c}151.33 \\
\pm 6.51\end{array}$ & $\begin{array}{c}153.67 \\
\pm 5.69\end{array}$ & $\begin{array}{c}149.81 \\
\pm 5.84\end{array}$ & $\begin{array}{c}153.21 \\
\pm 5.41\end{array}$ \\
\hline $\begin{array}{l}\text { Kumari S et } \\
\text { al., (2018) } \\
{[15]}\end{array}$ & East India & 50 & $\begin{array}{l}137.25 \\
\pm 10.85\end{array}$ & $\begin{array}{l}151.5 \\
\pm 1.66\end{array}$ & - & - \\
\hline $\begin{array}{l}\text { Present } \\
\text { study }\end{array}$ & East India & 54 & 139.6 & 149.3 & 145.8 & 151 \\
\hline
\end{tabular}

were also conducted on East Indian population [14,15]. Assessing and comparing the present data with the past studies reveals some differences as well as similarities with the present study.

\section{Limitation(s)}

As studies were very limited on East Indian population, so conclusion can not be made depending on these very few studies. In future, more studies should be done to determine the final result.

\section{CONCLUSION(S)}

In the present study, the average length of the clavicle on the left side is more than the right side in both sexes, the mean lateral angle of the left side of clavicles is more in male but it is less in case of female. In case of mean medial angle it is more on the left side in both sexes. These variations may be due to various factors such as racial, genetic or mechanical. These are specially important for Orthopaedic surgeons during operative procedures on this bone. The morphometric values also may help the anthropologists as well as the forensic experts.

\section{REFERENCES}

[1] Johnson D, Strong GT, Collins P, Healy JC. Pectoral girdle and upper limb. In: Susan Stranding (ed). Gray's Anatomy: The anatomical basis of clinical practice. $3^{\text {th }}$ edition. Elsevier Churchill Livingstone. London, 2005:817-819.

[2] Toogood P, Horst P, Samagh S, Feeley BT. Clavicle fractures: A review of the literature and update on treatment. Phys Sportsmed. 2011;39(3):142-50.

[3] Nagarchi K, Pillai TJ, Hussain Saheb S, Brekeit K, Alharbi M. Morphometry of clavicle. Journal of Pharmaceutical Science and Research. 2014;6(2):112-14.

[4] Sudha R. Study of clavicle: Length and curvatures in South Indian population National Journal of Clinical Anatomy. 2014;3(4):198-02.

[5] Parsons FG. On the proportions and characteristics of the modern English clavicle. J Anat.1916;51:71-93.

[6] Gullapalli A. Study of morphometry of clavicle-length \& angles. International Journal of Scientific Research. 2017;6(7):318-19.

[7] Terry RJ. The clavicle of the American Negro. Am J Phys Anthropol. 1932;16:351-79.

[8] Olivier G. Anthropologie de la Clavicule.III, La Clavicule due Francis. Bulltins et. Memories de la societe. D' Anthropologie. 1951;2:121-57.

[9] Jit I, Singh S. Estimation of stature from clavicles. Indian J Med Res. 1956;44(1):137-55.

[10] Haque MK, Mansur DI, Krishnamurthy A, Karki R, Sharma K, Shakya R. Morphometric analysis of clavicle in Nepalese population. Kathmandu Univ Med J. 2011;9(35):193-97. 
[11] Singh S, Gangrade KC. The sexing of adult clavicles: Demarking points for Varanasi zone. J Anat Soc India.1968;17:89-100.

[12] Kaur K, Rathee SK. Study of the clavicular curvatures in North Indian population. International Journal of Science and Research. 2017;6(3):180-82.

[13] Kaur H, Harjeet, Sahni D, Jit I. Length and curves of the clavicle in Northwest Indians. Journal of Anatomical Society of India. 2002;5920:199-09.
[14] Singh G, Das S, Shamal S. Patra M. Gender variation of Clavicle in Eastern Odisha. International journal of Anatomy and Research. 2020;8(1.3):7386-89.

[15] Kumari S, Verma M, Narayan RK. Role of clavicle curvature in fracture stabilization: A study in East Indian population. International Journal of Anatomy and Research. 2018;6(4.1):5811-14.

PARTICULARS OF CONTRIBUTORS:

1. Associate Professor, Department of Anatomy, Deben Mahata (Purulia) Government Medical College and Hospital, Purulia, West Bengal, India.

2. Associate Professor, Department of Anatomy, N R S Medical College and Hospital, Kolkata, West Bengal, India.

3. Senior Resident, Department of Anatomy, North Bengal Medical College and Hospital, Darjeeling, West Bengal, India.

NAME, ADDRESS, E-MAIL ID OF THE CORRESPONDING AUTHOR:

\section{Dr. Banani Kundu,}

Swabhumi Residency, P-12, Motijheel Avenue, Dumdum, Kolkata, West Bengal, India

E-mail: dr.bmitra@yahoo.com
PLAGIARISM CHECKING METHODS: [Jain Het al.]

- Plagiarism X-checker: Jul 27, 2020

- Manual Googling: Nov 20, 2020

- iThenticate Software: Jan 12, 2020 (14\%)
ETYMOLOGY: Author Origin

\section{AUTHOR DECLARATION}

- Financial or Other Competing Interests: None

- Was Ethics Committee Approval obtained for this study? No

- Was informed consent obtained from the subjects involved in the study? No

- For any images presented appropriate consent has been obtained from the subjects. No
Date of Submission: Jul 23, 2020

Date of Peer Review: Sep 17, 2020

Date of Acceptance: Nov 24, 2020

Date of Publishing: Apr 01, 2021 